\title{
ЕКОНОМІКА
}

$\begin{gathered}\text { Науковий вісник НлтУ України } \\ \text { Scientific Bulletin of UNFU } \\ \text { https://nv.nltu.edu.ua }\end{gathered}$
$\begin{aligned} & \text { https://doi.org/10.36930/40310415 } \\ & \text { Article received 02.06.2021 p. } \\ & \text { Article accepted 09.09.2021 p. } \\ & \text { UDC 339.1:630.[71+8] }\end{aligned}$
$\begin{aligned} & \text { ISSN 2519-2477 (online) } \\ & \text { A. S. Torosov }\end{aligned}$
$\begin{aligned} & \text { Correspondence author } \\ & \text { torosov@uriffm.org.ua }\end{aligned}$

A. C. Торосов, I. М. Жежкун

Украӥнський ордена "Знак потани" науково-дослідний інститут лісового господарства і агролісомеліорації ім. Г. М. Висоцького, м. Харків, Україна

\section{РЕГІОНАЛЬНА СТРУКТУРА ЗАГОТІВЛІ ТА СПОЖИВАННЯ ДЕРЕВИНИ В УКРАЇНІ}

Оцінено на регіональній основі виробництво та споживання деревини і виробів з неї. Дослідження регіональної структури виробництва та споживання деревини потребує збирання, групування й узагальнення значних обсягів інформації. Тому актуальними $є$ питання застосування сучасного різнопланового методичного інструментарію. При цьому з'ясовано складнощі законодавчо-методичного характеру, що перешкоджають проведенню детального аналізу ринку деревини. Встановлено, що вивчення ринку деревини ускладнюється, зокрема, через відсутність достатнього обсягу матеріалів у відкритому доступі для здійснення аналізу його сучасного стану. Під час економічних досліджень науковці пропонують такі методичні підходи до вивчення ринку деревини: експертний, на базі життєвого циклу лісопродукції, статистичний та моделювання. У дослідженні застосовано статистичний метод. Проведено розрахунки для 6-ти товарних груп круглого лісу та виробів 3 деревини (I - круглі лісоматеріали; II - деревне вугілля, тріска, стружка та деревні відходи, деревні пелети та інші агломерати; III пиломатеріали та шпон; IV - листові деревні матеріали; V - маса з деревини та рекуперований папір; VI - папір та картон) за статистичними даними міжнародної класифікації FAO. Наведено показники виробництва зазначених товарних груп продукції з деревини по областях України в розрізі природних зон за статистичними показниками Державної служби статистики України (2019р.). Визначено регіональну структуру виробництва та споживання деревини. З'ясовано, що виробничі потужності деревооброблення переважно зосереджені у лісозабезпечених областях Полісся, Карпат та Лісостепу, а окремі виробництва розміщені і в Степовій природній зоні, зокрема, у великих обласних центрах країни. Результати здійсненого аналізу дадуть змогу отримати потрібну інформацію щодо наявних обсягів, якісної характеристики деревного ресурсу, напрямів його реалізації та споживання як усередині країни, так і можливості експортування певних видів та обсягів деревної продукції. Оцінювання сучасного стану виробництва та споживання деревини є необхідною передумовою для прогнозування ринку деревини в країні.

Ключові слова: ринок деревини; круглі лісоматеріали; групи виробів з деревини; економічна оцінка; статистичні показники; обсяги випуску продукції.

\section{Вступ / Introduction}

Для забезпечення ефективного механізму стратегічного планування щодо обсягів заготівлі деревини та споживання виробів з неї необхідно отримати від контрагентів (підприємств лісогосподарської та деревообробних галузей, як постачальників та основних споживачів деревного ресурсу) об'єктивну інформацію щодо наявного круглого лісу та внутрішнього попиту на нього на регіональній основі. Зазначимо, що статистична інформація за обсягами заготівлі та реалізації необробленої деревини в розрізі областей України є доступною у відкритих джерелах [14]. Проте практично неможливо отримати достовірні дані щодо регіонального попиту на цей ресурс за напрямками використання (виготовленням видів продукції з деревини). Тому визна- чення обсягів фактичного використання та прогнозування за регіонами на середню та довготермінову перспективи ресурсів деревної сировини для деревообробного виробництва $є$ одним з основних завдань забезпечення ефективного функціонування ринку деревини у країні.

Об'єкт дослідження - регіональна структура виробництва та споживання деревини.

Предмет дослідження - науково-методичні та прикладні аспекти вивчення ринку деревини.

Мета роботи - застосування та розвиток науковометодичних та прикладних особливостей вивчення ринку деревини.

Для досягнення зазначеної мети визначено такі основні завдання дослідження: запровадити аналіз фактичного споживання заготовленої необробленої деревини за регіонами України згідно з міжнародною класифі-

\section{Інформація про авторів:}

Торосов Артем Сергійович, канд. екон. наук, ст. наук. співробітник, завідувач лабораторії економіки Email: torosov@uriffm.org.ua; https://orsid.org/0000-0001-7694-6773

Жежкун Ірина Миколаївна, канд. екон. наук, ст. наук. співробітник, лабораторія економіки. Email: zhezhkun.iruna@gmail.com; https://orsid.org/0000-0001-5314-7557

Цитування за ДСтУ: Торосов А. С., Жежкун І. М. Регіональна структура заготівлі та споживання деревини в Україні. Науковий вісник НЛтУ України. 2021, т. 31, № 4. С. 93-97.

Citation APA: Torosov, A. S., \& Zhezhkun, I. N. (2021). Regional structure of timber harvesting and consumption in Ukraine. Scientific Bulletin of UNFU, 31(4), 93-97. https://doi.org/10.36930/40310415 
кацією виробів з деревини; визначити обсяги і структуру заготівлі круглих лісоматеріалів та випуску продукції деревооброблення за адміністративними областями та природними зонами України.

Наукова новизна отриманих результатів дослідження - отримали подальший розвиток наявних, впровадження нових науково-методичних і прикладних аспектів вивчення ринку деревини.

Практична значущість результатів дослідження науково-практичні результати можуть використовувати суб'єкти управління та господарювання під час планування і прогнозування виробництва та споживання деревини на регіональній основі.

Аналіз останніх досліджень та публікацій. Дослідженням ринку деревини в Україні, як комплексу галузей $з$ виробництва (лісове господарство) та споживання деревини (деревообробна промисловість), у вітчизняній науковій літературі приділено мало уваги. Сучасні наукові дослідження мають не комплексний [4], а локальний характер, тобто спрямовані на вирішення окремих вузьких проблем [2]. За наявності під час вивчення ринків деревини експертних оцінок $[9,10]$, на базі життєвого циклу лісопродукції [11], моделювання [7], статистичний метод залишається найбільш об'єктивним і точним [1]. Зазначимо, що недоліком використання статистичного методу дослідження ринку деревини в Україні $\epsilon$ відображення тільки легального його обігу. Частина деревообробних, особливо малих підприємств, в Україні використовує деревну сировину, придбану нелегально, яку статистична служба не враховує.

Останнім часом актуальними в Україні постають питання напрацювань ефективних механізмів функціонування ринку деревини [6]. У розвинених європейських країнах такі механізми напрацьовані і вже розглядають сучасні макроекономічні проблеми лісового сектору, зокрема, прогнозування попиту на окремі види продукції $з$ деревини [8], впливу на попит та ціни на регіональних ринках деревини надзвичайних ситуацій природного характеру, що знищують лісові масиви на великих площах [12], втрат економіки від картельних змов покупців необробленої деревини [5], ефективності певних механізмів продажу цінних сортиментів деревини [16] тощо. За розглянутим спектром науково-прикладних підходів до аналізу ринку виробництва та споживання деревини найприйнятнішим визначено застосування статистичного методу дослідження [1].

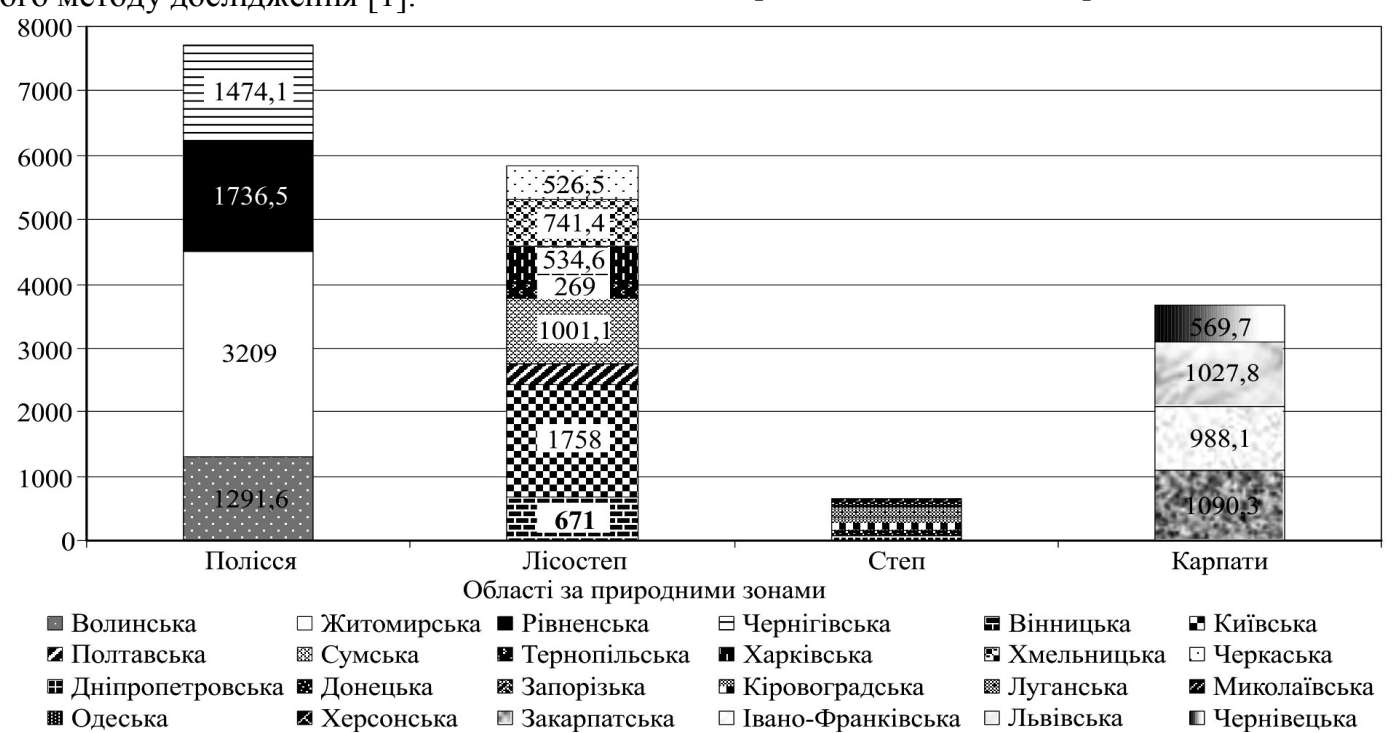

Рис. 1. Обсяги заготовленого круглого лісу за областями та природними зонами, тис. $\mathrm{m}^{3} /$ Volumes of harvested roundwood by regions and natural areas, thousand $\mathrm{m}^{3}$
Матеріали та методи дослідження. Статистична класифікація продукції в Україні виділяє на ринку деревини близько 100 категорій товарів 3 різною доданою вартістю [4], що ускладнює процес вивчення обсягів її споживання за видами. За відсутності статистичних даних щодо напрямків використання підприємствами деревообробних галузей (деревообробної, паперової, лісохімічної) обсягів придбаного круглого лісу та відходів деревини опосередковано отримати інформацію щодо регіонального (за областями України) галузевого попиту на продукцію необробленої деревини можливо через аналіз за областями обсягів виробництва відповідних груп та видів продукції деревооброблення. Згідно з міжнародною класифікацією FAO вироби з деревини об'єднуються у 6 товарних груп (I - круглий ліс; II - деревне вугілля, тріска, стружка та деревні відходи, деревні пелети та інші агломерати; III - пиломатеріали та шпон; IV - листові деревні матеріали; V - деревна маса та рекуперований папір; VI - папір та картон) [3].

Заготівлю [14] та споживання деревини за адміністративними областями України [13] оцінювали з використанням статистичного методу дослідження. Для цього відповідні дані за номенклатурою виробів 3 деревини [13] було згруповано відповідно до наведеної вище міжнародної класифікації [3]. Проте за певними товарними групами частина інформації щодо обсягів виробництва деревної продукції є конфіденційною згідно 3 вимогами чинного законодавства [15] і в розрахунках подають як "не опубліковані дані". У дослідженні застосовано кількісні методи статистики, групування, порівняння, табличного та графічного моделювання, економічного аналізу та синтезу, економіко-математичні методи кореляційного аналізу. Кореляційний аналіз здійснювали стандартним програмним забезпеченням Microsoft Office Excel 2003.

\section{Результати дослідження та їх обговорення / Research results and their discussion}

Визначено регіональну структуру заготівлі круглого лісу (рис. 1) та внутрішнього споживання деревини інших товарних груп продукції 3 деревини (рис. 2-4). Встановлено за природними зонами України тісноту зв'язку (кореляції) між обсягами заготівлі деревини та виробництвом пиломатеріалів. 


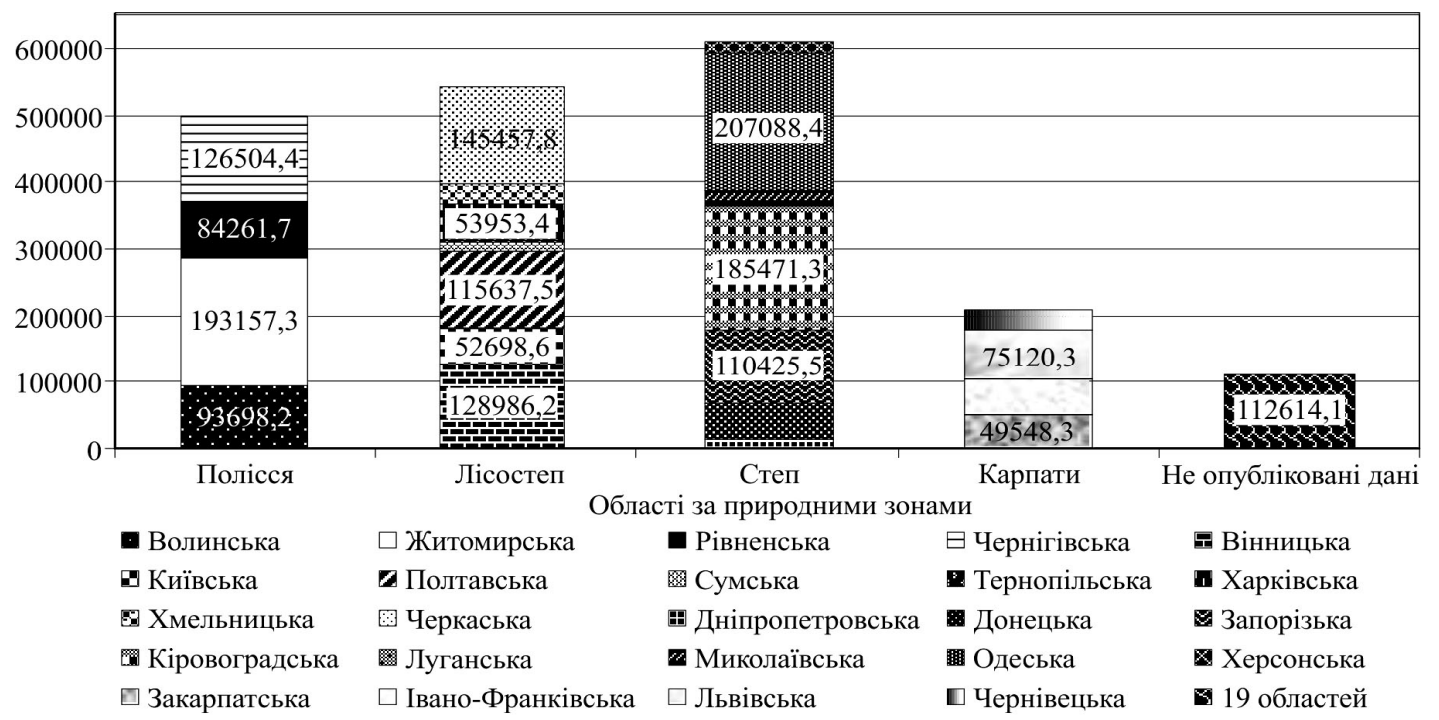

Рис. 2. Обсяги випуску II групи виробів з деревини за областями та природними зонами, т / Volumes of production of the 2nd group of wood products by regions and natural areas, tons

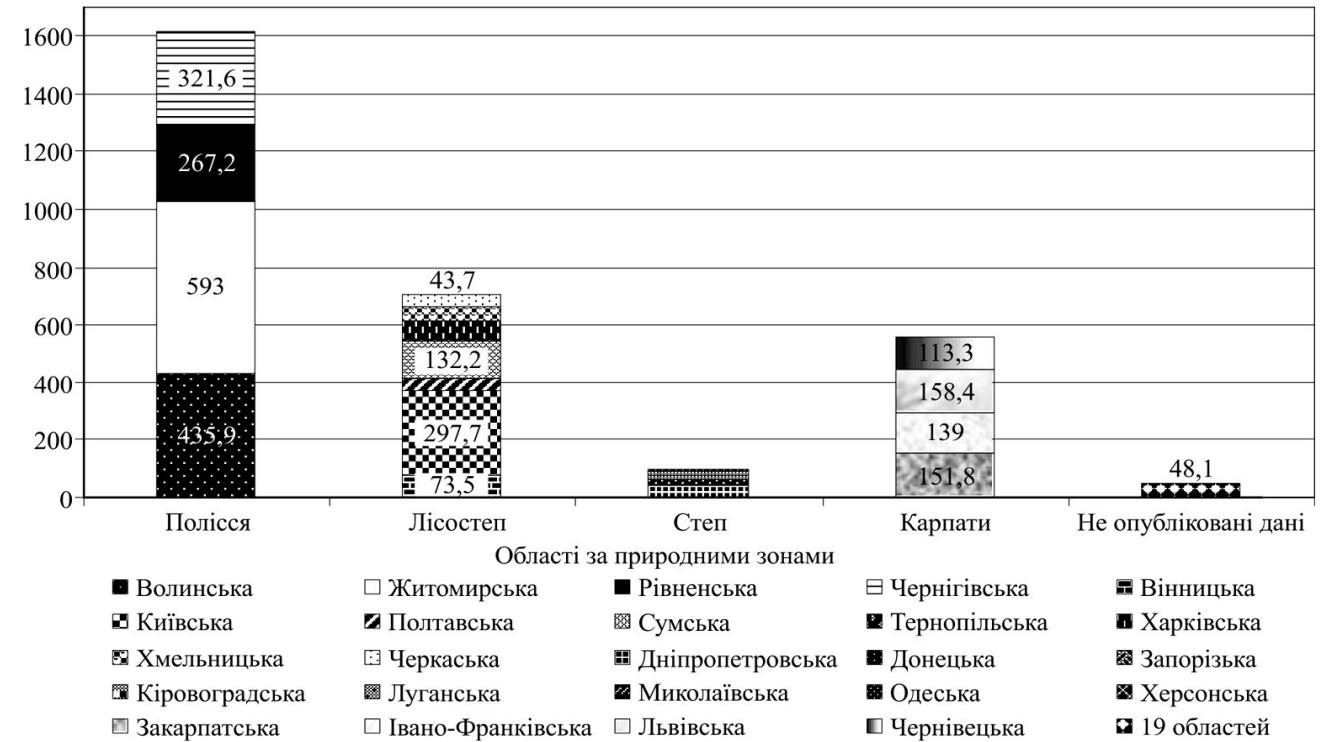

Рис. 3. Обсяги випуску пиломатеріалів за областями та природними зонами, тис. $\mathrm{m}^{3}$ / Volumes of sawnwood by regions and natural areas, thousand $\mathrm{m}^{3}$

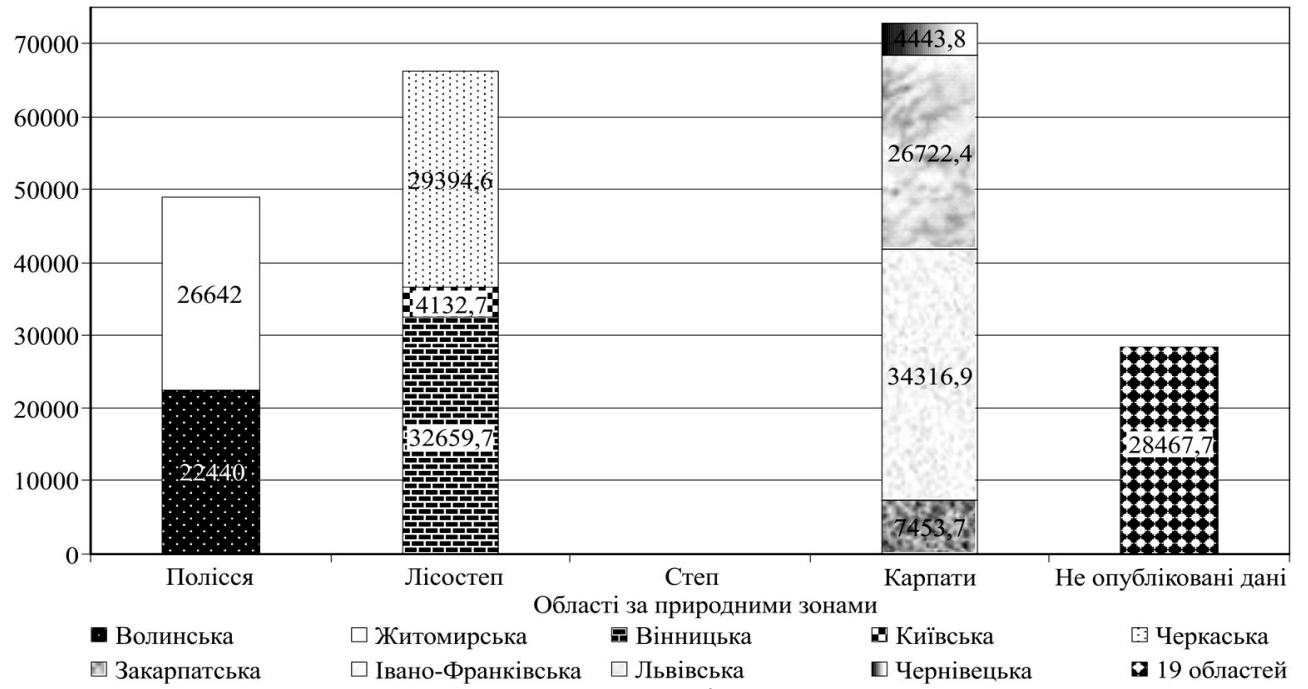

Рис. 4. Обсяги випуску шпону за областями та природними зонами, $\mathrm{m}^{3} /$ Volumes of veneer sheets by regions and natural areas, $\mathrm{m}^{3}$

Показники виробництва зазначених товарних груп круглих лісоматеріалів та продукції з деревини наведено за 2019 р. для областей України в розрізі природних зон за статистичними матеріалами Державної служби статистики України.
Обговорення результатів дослідження. У структуpi заготівлі річних обсягів круглого лісу $42 \%$ $\left(7711,2\right.$ тис. $\left.\mathbf{m}^{3}\right)$ припадає на Поліську природну зону, $33 \%$ (5842,9 тис. м $\left.^{3}\right)$ - на Лісостепову, $21 \%$ $\left(3217,8\right.$ тис. $\left.{ }^{3}\right)$ - на Карпатський регіон та тільки $4 \%$ 
(656,6 тис. м $^{3}$ ) - на Степову природну зону (див. рис. 1). Безперечним лідером за кількістю заготівлі круглого лісу була Житомирська область (17,4 \% від загального обсягу); 9,8 \% заготовляли в Київській, 8,5\% - Рівненській, 7,8 \% - Чернігівській та 7,3 \% - Волинській областях. Спостерігається тісний кореляційний зв'язок в лісозабезпечених регіонах між обсягами заготівлі круглого лісу та виробництвом пиломатеріалів (розташуванням виробничих потужностей з первинного деревооброблення). Коефіцієнт кореляції між зазначеними показниками: Лісостепова природна зона - $(r=0,9744)$, Карпатський регіон - $(\mathrm{r}=0,9393)$, зона Полісся - $(r=$ $0,7562)$; Степова частина - $(r=0,2306)$.

Територіальний розподіл за природними зонами виготовлення продукції II групи виробів 3 деревини (деревного вугілля, тріски, відходів, пелет та інших агломератів) був відносно рівномірним: $25 \%$ обсягів виробляли в областях Полісся, $28 \%$ - Лісостепу, $30 \%$ - Степу та ще $11 \%$ - Карпат; інформація щодо $6 \%$ обсягів виробництва $\epsilon$ конфіденційною (дтв. рис. 2). Вироби цієї групи виготовляли у всіх областях України.

Областями-лідерами за обсягами виробництва продукції II групи виробів 3 деревини були дві області Степової природної зони (Одеська - 10,5\% та Кіровоградська - 9,4 \%), одна область Полісся (Житомирська 9,8 \%) та одна Лісостепу (Черкаська - 7,4\%); разом частка цих чотирьох областей у загальному обсязі виробництва зазначеної групи виробів 3 деревини становила $37,1 \%$.

У 2019 р. переважна більшість обсягів виробленої продукції первинного деревооброблення - III група виробів 3 деревини - пиломатеріалів (див. рис. 3) та шпону (див. рис. 4) була зосереджена у Поліській (53\%), Лісостеповій (23\%) та Карпатській (19\%) природних зонах. На підприємствах Степової природної зони виробляли тільки 3 \% обсягів продукції цієї групи.

Виготовлення пиломатеріалів у 2019 р. відбувалось у всіх областях України, а шпону - у 16 областях (67 \%): у всіх 4-х областях Карпатського регіону, у 3-х областях Полісся (окрім Чернігівської), 6-ти областях Лісостепу (окрім Полтавської та Харківської), у 3-х (Кіровоградській, Одеській та Херсонській) 3 8-ми областей Степу.

Найбільше пиломатеріалів виробляли в 4-х областях Полісся: 19,5 \% у Житомирській, 14,4 \% у Волинській, 10,6 \% у Чернігівській та 8,8 \% у Рівненській. На другому місці за обсягами виготовлення пиломатеріалів перебували 4 області Карпатського регіону: 5,2 \% у Львівській, 5,0 \% у Закарпатській, 4,6 \% у Івано-Франківській та 3,7 \% у Чернівецькій. Областями-лідерами за обсягами виробництва пиломатеріалів у Лісостеповій природній зоні були дві: Київська та м. Київ - 9,8 \% та Сумська $-4,4 \%$. У решті 6 областях Лісостепу виготовляли менше 10 \% від загального по Україні обсягу пиломатеріалів (від 0,2 до 2,4\% за деякими областями). Максимальною часткою (близько 1,4\%) за обсягами виробництва пиломатеріалів у Степовій природній зоні характеризувалась Дніпропетровська область.

Найбільше шпону виробляли у Карпатському регіоні (33\%). Частка Лісостепу становила $31 \%$ та Полісся - $23 \%$. Областями-лідерами за річними обсягами виробництва шпону за обсягів понад 30,0 тис. м ${ }^{3}$ були Івано-Франківська (34,3 тис. м ${ }^{3}$ або $15,8 \%$ ) та Вінницька (32,7 тис. $\mathrm{m}^{3}$ або $\left.15,1 \%\right)$.
Ще в 4-х областях у 2019 р. виготовляли шпон в обсягах понад 20 тис. м $^{3}$, але менше 30,0 тис. м $^{3}$ : у Черкаській - 29,4 тис. м ${ }^{3}$ або 13,6\%, у Львівській 26,7 тис. м $^{3}$ або $12,3 \%$, Житомирській $-26,6$ тис. м ${ }^{3}$ або $12,3 \%$ та Волинській - 22,4 тис. м ${ }^{3}$ або 10,4 \%. Разом у згаданих 6 областях у 2019 р. виробляли майже 80,0 \% від загальних обсягів шпону, а у решті 10 областях всього $20 \%$.

Відкрита інформація Державної служби статистики України щодо обсягів виробництва за областями у 2019 р. інших 3-х груп виробів 3 деревини (IV - листових матеріалів, V - маси 3 деревини 3 деревини та рекуперованого паперу, VI - паперу та картону) має неповний та епізодичний характер, що не дає можливості для проведення детального аналізу. Тому, за відсутністю показників обсягів виробництва, наводимо статистичні дані тільки за переліком областей, де виробляли зазначену продукцію з деревини.

За територіальним розміщенням виробничих потужностей виробництво фанери зосереджено у Поліському, Карпатському та Лісостеповому регіонах України. У Степовій природній зоні фанеру випускали у Дніпропетровській і Кіровоградській областях.

Підприємства 3 виробництва ДСП розташовані у 4-х областях Карпатського регіону, 3-х областях Полісся (окрім Чернігівської області), 7-ми областях Лісостепу (окрім Полтавської) та 3-х областях Степу (Дніпропетровській, Кіровоградській та Одеській). Зазначимо, що у Степовій природній зоні виробництво фанери та ДСП зосереджено в обласних центрах-мегаполісах (міста Дніпро, Одеса).

Виробництво ДВП (на відміну від двох попередніх видів листових деревних матеріалів) за територіальним розміщенням є більш концентрованим (всього в 6-ти областях 3-х природних зон), зокрема, у 3-х областях Лісостепу (Київській, Сумській та Хмельницькій), 2-х областях Полісся (Житомирській та Чернігівській) та одній області Карпатського регіону (насамперед ІваноФранківській).

Ще більш територіально концентрованим в Україні $\epsilon$ розміщення виробничих потужностей з виготовлення деревних матеріалів V групи. Так, у 2019 р. масу з деревини виробляли тільки у двох областях - Волинській та Хмельницькій. Перероблення рекуперованого паперу (макулатури) здійснювали в 4-х областях - Київській, Хмельницькій, Луганській та Львівській.

На відміну від V групи виробів 3 деревини виробництво паперу та картону (VI група виробів 3 деревини) здійснювали у 19-х областях. Не виробляли паперову та картонну продукцію тільки в 5-ти областях, що територіально розміщені в 3-х природних зонах: Вінницькій та Полтавській (Лісостеп), Кіровоградській (Степ), Івано-Франківській і Чернівецькій областях (Карпати).

\section{Висновки / Conclusions}

Нестача повної та достовірної інформації щодо обсягів та структури використання в регіонах України необробленої деревини за напрямками споживання ускладнює процес забезпечення сталого розвитку деревообробних галузей. 3 розглянутих методичних підходів 3 вивчення ринку деревини у статті застосовано статистичний, який грунтується на інформації Державної служби статистики України. Для цього відповідні ста- 
тистичні дані за номенклатурою виробів з деревини були згруповані у 6 товарних груп згідно з міжнародною класифікацією FАO (круглий ліс; деревне вугілля, тріска, стружка та деревні відходи, деревні пелети та інші агломерати; пиломатеріали та шпон; листові деревні матеріали; маса з деревини та рекуперований папір; папір та картон). Аналіз територіального розміщення підприємств та обсягів виготовлення за природними зонами в Україні продукції первинного деревооброблення (пиломатеріалів та шпону) вказує на їх тяжіння до лісозабезпечених регіонів України (Полісся, Карпат, частково Лісостепу); частка виробничих потужностей розташована у Степовій зоні поблизу великих міст - ринків збуту продукції (Одеса, Дніпро). Певні деревообробні підприємства випускають продукцію 3 великою доданою вартістю (ДВП, рекуперований папір та картон), виробництво яких територіально концентровано тільки в декількох областях. Порівняно рівномірне за обсягами виготовлення у розглянутих природних зонах України продукції деревини II групи (деревне вугілля, тріска, стружка та деревні відходи, деревні пелети та інші агломерати) демонструє меншу залежність відповідних деревообробних підприємств від обсягів заготівлі ділового круглого лісу та здатність працювати на низькоякісній дров'яній сировині та відходах лісопильного та лісозаготівельного виробництв. Подальші дослідження передбачатимуть проведення багатоваріантного прогностичного аналізу виробництва та споживання деревини за різними сценаріями розвитку економіки в середньо- та довготерміновій перспективах.

\section{References}

1. Ajani, J. (2011). The global wood market, wood resource productivity and trends: an examination with special attention to China. Environmental Conservation, Vol. 1, 53-63. https://doi.org/ $\underline{10.1017 / \mathrm{S} 0376892910000895}$

2. Cherchyk, L., \& Behun, L. (2018). Statistical investigation of wood exports in Ukraine. Ekonomichnyi chasopys Skhidnoievropeiskoho natsionalnoho universytetu imeni Lesi Ukrainky, No. 3, 102 109. https://doi.org/10.29038/2411-4014-2018-03-102-109

3. Ezhegodnik lesnoj produkcii FAO 2018. (2018). Retrieved from: http://www.fao.org/3/cb0513m/CB0513M.pdf

4. Goncharuk, O., Zablotsky, A., \& Georgian, I. (2017). Green book. Timber market regulation. FORBIZ, 111 p. Retrieved from:
https://regulation.blob.core.windows.net/reg-blob/Green\%20Book\%20-\%20Wood.pdf

5. Kuuluvainen, J., Korhonen, J., Wang, L., \& Toppinen, A. (2021). Wood market cartel in Finland 1997-2004: Analyzing price effects using the indicator approach. Forest Policy and Economics. Vol. 124, 123-129. https://doi.org/10.1016/j.forpol.2020.102380

6. Kuzmenko, Ye. (2021). How the timber market will react to the lifting of the moratorium. Retrieved from: https://eba.com.ua/yakrynok-derevyny-vidreaguye-na-skasuvannya-moratoriyu/

7. Larocque, G., Mailly, D., \& Gaudreault, M. (2009). Forest modelling in Quebec: Context, challenges and perspectives. The Forestry Chronicle, Vol. 5, 702-705. https://doi.org/10.5558/ tfc85702-5

8. Maarit, A., \& Kallio, I. (2020). Wood-based textile fiber market as part of the global forest-based bioeconomy. Forest Policy and Economics, Vol. 123, 87-91. https://doi.org/10.1016/j.forpol.2020.102364

9. Purwestri, R., Hájek, M., Šodková, M., \& Jarský, V. (2020). How are Wood and Non-wood forest products Utilized in the Czech Republic? A Preliminary Assessment of a Nationwide Survey on the Bioeconomy. Sustainability, Vol. 2, 566 p. https://doi.org/10.3390/su12020566

10. Rule, L., \& OLaughlin, J. (1989). Expert Opinions on the Future Production of Five Manufactured Wood Products in the Pacific Northwest. Western Journal of Applied Forestry, 4(3), 92-98. https://doi.org/10.1093/wjaf/4.3.92

11. Sahoo, K., Bergman, R., Alanya-Rosenbaum, S., Gu, H., \& Liang, S. (2019). Life Cycle Assessment of Forest-Based Products: A Review. Sustainability, Vol. 17, 4722 p. https://doi.org/ 10.3390/su11174722

12. Udali, A., Andrighetto, N., Grigolato, St., \& Paola Gatto, P. (2021). Economic Impacts of Forest Storms - Taking Stock of After-Vaia Situation of Local Roundwood Markets in Northeastern Italy. Forests, Vol. 4, $414 \quad$ p. https://doi.org/10.3390/f12040414

13. Vyrobnytstvo promyslovoi produktsii za vydamy po rehionakh za 2019. (2019). Retrieved from: http://www.ukrstat.gov.ua/

14. Zahotivlia derevyny po rehionakh (2000-2020). Retrieved from: http://www.ukrstat.gov.ua/

15. Zakon Ukrainy. (2014). Zakon Ukrainy "Pro derzhavnu statystyku" VVR, No. 4, 816 p. Retrieved from: https://zakon.rada.gov.ua/laws/show/2614-12\#Text

16. Zastocki, D., Oktaba, J., \& Lachowicz, H. (2021). Changes in the Market of Precious Wood: A Case Study of Submission System in Poland. Forests, Vol. 4, 421 p. https://oi.org/10.3390/f12040421

A. S. Torosov, I. N. Zhezhkun Ukrainian Research Institute of Forestry and Forest Melioration named after G. M. Vysotsky, Kharkiv, Ukraine

\section{REGIONAL STRUCTURE OF TIMBER HARVESTING AND CONSUMPTION IN UKRAINE}

The availability of objective information on the regional structure of the timber market in the country is a necessary prerequisite for the formation of a strategy for the development of the forestry and woodworking industries of the country. Therefore, the research considers a wide range of methodological approaches to the study of the wood market. It is established that to assess the current state of production and consumption of wood in the country it is advisable to use statistical research methods. Calculations are made for the following 6 commodity groups of roundwood and wood products according to the statistics of the international classification FAO: I) roundwood; II) wood charcoal, wood chips, wood residues, wood pellets and other agglomerates; III) sawnwood and veneer sheets; IV) wood-based panels; V) wood pulp and recovered paper; VI) paper and paperboard. The indicators of production of these commodity groups of wood products by regions of Ukraine in terms of natural areas according to the statistical indicators of the State Statistics Service of Ukraine (2019) are given. The regional structure of wood production and consumption by regions within the natural zones of Ukraine, in particular, Polissya, Forest-Steppe, Carpathians, Steppe, are determined. A significant share of timber is harvested in areas that belong by the north, west and part of the center of the country. Differentiation of timber harvesting by regions is due to the available wood resources and their species composition. Comparison of roundwood harvesting by regions and the corresponding regional structure of its consumption indicates the concentration of woodworking production capacities mainly in the forest-covered oblasts of Polissya, Carpathians and Forest-Steppe, and some productions located in the Steppe natural zone, in particular, in large regional centers. In conclusion, the assessment of the current state of timber production and consumption is a necessary prerequisite for forecasting the timber market in the country. Further research will involve a multivariate forecast analysis of wood production and consumption under different scenarios of forestry development in the medium and long terms.

Keywords: wood market; roundwood; groups of wood products; economic evaluation; statistical indicators; production volume. 